\title{
PREFERENSI PRODUSEN BABI GULING TERHADAP BABI BALI SEBAGAI BAHAN BAKU
}

\author{
SUKANATA, I W., B. R. T. PUTRI, DAN SUCIANI \\ Program Studi Peternakan, Fakultas Peternakan Universitas Udayana \\ e-mail: nata_suka@yahoo.com
}

\begin{abstract}
ABSTRAK
Penelitian mempelajari atribut-atribut utama pada babi bali yang menjadi kesukaan produsen babi guling sebagai bahan baku babi guling. Data yang digunakan merupakan data primer yang dikumpulkan dengan teknik wawancara dan observasi terhadap responden yang merupakan produsen babi guling yang ada di sembilan kabupaten/kota di Bali. Lima puluh orang pedagang babi bali guling telah diwawancarai dengan bantuan kuisioner. Data dianalisis dengan analisis Chi Square dan analisis multiatribut Fishbein. Hasil penelitian menunjukkan bahwa terdapat perbedaan preferensi responden terhadap atribut-atribut warna, jenis kelamin, ukuran tubuh, dan kondisi tubuh secara nyata pada taraf kepercayaan 95\%. Babi bali yang lebih disukai oleh responden sebagai bahan baku babi guling adalah babi bali jantan yang berwarna hitam dengan berat sekitar 10-15 kg dan kondisi tubuhnya gemuk. Atribut babi bali yang dipertimbangkan oleh produsen babi guling dalam menentukan keputusan pembelian babi bali sebagai bahan baku babi guling, berturut-turut dari yang paling dipertimbangkan sampai dengan yang kurang dipertimbangkan adalah ukuran tubuh, kondisi tubuh, jenis kelamin dan warna. Atribut kondisi tubuh babi bali kurang memuaskan bagi responden yang ditunjukkan oleh nilai kepercayaan atau keyakinan yang hanya 2,9 dari nilai maksimum 5, sehingga di masa yang akan datang peternak sangat penting untuk memperhatikannya.
\end{abstract}

Kata kunci: preferensi, warna, jenis kelamin, ukuran, kondisi tubuh

\section{BALI PIGS PREFERENCE AS RAW MATERIALS FOR SUCKLING PIG}

\begin{abstract}
This study aims at observing the main attributes of bali pigs that prefer as a raw material suckling pig producer. Farmers have to know this thing in order to increase consumer satisfaction and their loyality. The data used interview and observation as primary data collected to fifty producers of suckling pig which is located in Bali. They were interviewed using questionnaires and analyzed with chi square and multiatribut Fishbein analysis. It showed that preferences of producers based on attributes of color, gender, body size and body condition significantly differ within 95\% level of interest. Bali pig attributes that preferred by the producer as a raw material of roasted pig is bali pig with balck colour, sex of male, $10 \mathrm{up}$ to $15 \mathrm{~kg}$ of body weight and fat body condition. The bali pig attributes considered by the producer in making decision to buy from the most consideration to the minimum such as body size, body condition, gender, and color. Body condition attribute was considered to be less satisfying for producers indicated with satisfaction score 2.9 from the maximum score of 5. So, it is important that farmers should pay attention to these attributes in the future.
\end{abstract}

Keywords: preferences, color, sex, body size, body condition

\section{PENDAHULUAN}

Salah satu jenis babi yang banyak dipelihara di Bali dan menjadi sumber pendapatan bagi masyarakat terutama di daerah marginal adalah babi bali. Babi bali merupakan sumber plasma nutfah yang harus dilestarikan (Budaarsa et al., 2016). Babi bali memiliki berbagai keunggulan dibandingkan babi ras, seperti lebih tahan terhadap lingkungan/cuaca yang ekstrim, dapat tumbuh dengan baik walaupun pakan yang diberikan seadanya, serta hemat air. Keunggulan tersebut membuat babi jenis ini menjadi pilihan petani di daerah-daerah marginal di Bali karena di daerah itu ia masih mampu berproduksi dengan baik. Di samping itu, daging babi bali memiliki citarasa yang lebih gurih, dan sangat cocok dipakai sebagai babi guling. Bahkan, di beberapa daerah, masih fanatik harus menggunakan babi bali sebagai babi guling.

Pemasaran ternak babi merupakan suatu proses kegiatan untuk mentransformasi hasil produksi berupa 
babi menjadi pendapatan berupa uang secara berkelanjutan. Pemasaran tersebut sangat penting untuk diperhatikan karena akan sangat mempengaruhi pendapatan peternak dan keberlanjutan dari usahatani tersebut. Sistem pemasaran yang lebih baik akan dapat memberikan pendapatan yang lebih besar kepada petani, dan sebaliknya.

Salah satu aspek pemasaran yang sangat penting untuk diperhatikan adalah preferensi konsumen. Produsen babi guling merupakan konsumen yang terbanyak menggunakan babi bali sebagai bahan baku babi guling. Tujuan utama dari penelitian ini adalah untuk menentukan atribut-atribut utama pada babi bali yang menjadi kesukaan (preferensi) bagi pedagang babi guling dan merangking atribut-atribut tersebut dari yang paling disukai sampai dengan yang kurang disukai. Hal ini sangat penting diketahui oleh peternak sehingga dapat meningkatkan kepuasan dan loyalitas konsumen dalam mendukung daya saing peternak. Selama ini belum ada kajian mengenai preferensi produsen babi guling terhadap babi bali sebagai bahan bakunya, sehingga peternak belum mengetahui secara pasti atribut-atribut apa yang disukai oleh produsen babi guling tersebut. Oleh karena itu, penelitian ini sangat penting untuk dilaksanakan. Hasilnya diharapkan akan dapat menjadi bahan pertimbangan terutama bagi peternak dalam menyusun rencana produksi sehingga babi yang dihasilkan dapat memuaskan konsumen.

\section{METODE PENELITIAN}

Penelitian ini merupakan penelitian survei yang dilaksanakan di Kota Denpasar dan delapan kota di masing-masing kabupaten di Bali. Penelitian ini dilaksanakan sejak bulan Juli hingga Oktober 2016. Jenis data yang dipergunakan dalam penelitian ini berupa data primer yaitu data yang dikumpulkan langsung dari responden melalui pengamatan dan wawancara langsung terhadap responden. Wawancara dilakukan secara terstruktur dengan bantuan kuisioner. Responden dalam penelitian ini adalah produsen babi guling yang membuat babi guling dari babi bali yang berjumlah 50 orang.

Analisis Chi Square digunakan untuk mengetahui preferensi produsen babi guling terhadap babi bali dengan rumus sebagai berikut (Siegel, 1997):

$$
X^{2}=\sum_{i=1}^{k}\left[\frac{(f o-f e)^{2}}{f e}\right]
$$

di mana:

$\chi^{2}$ : Chi kuadrat

fo : frekuensi observasi

fe : frekuensi yang diharapkan

i...k : kategori atribut babi bali
Frekuensi yang diharapkan dapat ditentukan dengan rumus (Wirawan, 2002):

$$
f e=\frac{\sum f_{o}}{n}
$$

di mana: $\mathrm{n}=$ jumlah kategori atribut

Hipotesis yang digunakan:

Ho : tidak terdapat perbedaan preferensi produsen terhadap atribut yang ada pada babi bali

Ha : terdapat perbedaan preferensi produsen terhadap atribut yang ada pada babi bali

Pengujian pada tingkat kepercayaan 95\% dengan kriteria pengujian:

Ho ditolak jika $\chi^{2}$ hitung $>\chi^{2}$ tabel

Ho diterima jika $\chi^{2}$ hitung $\leq \chi^{2}$ tabel

Analisis multiatribut Fishbein digunakan untuk mengetahui atribut-atribut babi bali dari yang paling dipertimbangkan sampai dengan yang kurang dipertimbangkan dalam keputusan pembelian babi bali oleh produsen babi guling, dengan rumus sebagai berikut:

$$
A_{0}=\sum_{i=1}^{n} b_{i} e_{i}
$$

Keterangan:

Ao: sikap produsen babi guling terhadap babi bali

bi : tingkat kepercayaan produsen babi guling bahwa babi bali yang dibeli memiliki atribut tertentu (variabel ke-i).

ei : dimensi evaluatif (evaluasi) produsen babi guling atau tingkat kepentingan atribut/variabel ke-i yang dimiliki babi bali

\section{Langkah-langkah analisis:}

1. Menentukan penilaian kepercayaan terhadap atribut babi bali $\left(b_{i}\right)$ dengan cara menentukan standar penilaian (scoring) dengan menggunakan skala likert, yaitu:

5 untuk sangat baik

4 untuk baik

3 untuk netral

2 untuk tidak baik

1 untuk sangat tidak baik

2. Mencari nilai kepercayaan dan evaluasi produsen babi guling terhadap babi bali dilakukan dengan cara berikut:

$$
b_{i} \text { atau } e_{i}=\frac{5 a+4 b+3 c+2 d+e}{a+b+c+d+e}
$$

Keterangan:

bi : nilai kepercayaan/evaluasi produsen babi guling terhadap babi bali

ei : nilai evaluai (tingkat kepentingan) produsen babi guling terhadap babi bali

a : jumlah produsen babi guling yang memilih sangat baik/ penting

$\mathrm{b}$ : jumlah produsen babi guling yang memilih baik / penting 
$\mathrm{c}$ : jumlah produsen babi guling yang memilih netral

$\mathrm{d}$ : jumlah produsen babi guling yang memilih tidak baik / penting

e : jumlah produsen babi guling yang memilih sangat tidak baik/ penting

Nilai $A_{o}$ yang tertinggi menunjukkan bahwa atribut tersebut merupakan atribut yang paling dominan dipertimbangkan oleh produsen babi guling dalam membeli babi bali.

\section{HASIL DAN PEMBAHASAN}

\section{Karakteristik Responden dan Gambaran Umum Usaha}

Umur responden berkisar antara 30- 62 tahun dan $52 \%$ berada pada kelompok umur $30-40$ tahun. Tingkat pendidikan responden sudah lumayan tinggi, $64 \%$ berpendidikan SMA dan bahkan berpendidikan S1 sebanyak $10 \%$.

Usaha babi guling yang dilakukan responden merupakan usaha pokok sebagai sumber penghasilan dan merupakan usaha keluarga yang diwariskan secara turun-temurun. Namun demikian, sebagian besar dari usaha ini tidak mempunyai warung untuk menjajakan babi gulingnya. Hanya 20\% dari responden yang mempunyai warung babi guling. Responden membuat babi guling adalah berdasarkan pesanan. Konsumen yang biasanya memesan babi guling adalah orang pribadi, pedagang banten, hotel/restoran, dan organisasi lainnya. Sebagian besar konsumen biasanya membeli babi guling babi bali sebagai pelengkap upakara yadnya (sesajen), disamping juga untuk dikonsumsi langsung (pesta).

Responden umumnya memperoleh babi bali hidup sebagai bahan baku utama babi guling dari suplier. Sebagian besar dari mereka (52\%) melakukan pembelian sebanyak dua kali dalam seminggu, dengan rata-rata jumlah pembelian sebanyak 10-15 ekor dalam satu kali transaksi. Responden menyatakan bahwa babi bali sangat disukai oleh konsumen sebagai babi guling karena berbagai alasan yaitu: 1) memiliki cita rasa yang lebih kuat, enak, dan gurih dibandingkan babi ras, 2) kulit babi guling yang dihasilkan dari babi bali lebih empuk dan mampu bertahan dalam jangka waktu yang lebih lama dibandingkan babi ras. Hal ini sejalan dengan Budaarsa (2012; 2014) yang menyatakan bahwa babi bali memiliki citarasa yang lebih gurih, dan sangat cocok dipakai sebagai babi guling. Ia menambahkan bahwa babi bali merupakan babi tipe lemak, memiliki lemak punggung yang lebih tebal, sehingga akan menghasilkan kulit babi guling yang lebih tebal dan lebih empuk dibandingkan babi ras. Kulit babi guling merupakan bagian dari babi guling yang paling disukai oleh konsumen. Selain itu ia juga menjelaskan bahwa lemak di bawah kulit pada babi bali ketika diguling akan mencair dan meresap ke dalam daging serta keluar melumuri kulit dan memberi aroma yang spesifik. Hal ini juga didukung oleh Suarna dan Suryani (2014) yang menyatakan bahwa babi bali sangat potensial sebagai babi guling karena komposisi lipatan lemak di bawah kulit akan memberikan aroma dan tekstur babi guling yang sangat baik. Kelebihan tersebut membuat permintaan babi bali untuk dijadikan babi guling sangat tinggi.

\section{Preferensi Responden terhadap Atribut-Atribut Babi Bali}

Preferensi responden terhadap babi bali merupakan pilihan suka atau tidak suka responden terhadap babi bali yang akan digunakan sebagai bahan baku babi guling. Hasil analisis Chi Square mengenai preferensi responden menunjukkan bahwa atribut warna, jenis kelamin, ukuran tubuh dan kondisi tubuh berbeda nyata dalam taraf kepercayaan $95 \%$. Artinya, preferensi responden terhadap atribut warna, jenis kelamin, ukuran tubuh, dan kondisi tubuh tidak sama atau terdapat perbedaan preferensi responden terhadap atribut-atribut tersebut secara nyata, seperti yang dapat dilihat pada Tabel 1 .

\begin{tabular}{lcccc} 
Tabel 1. Hasil analisis Chi Square \\
\hline Atribut Babi Bali & $\mathrm{X}^{2}$ hitung & Df & $\mathrm{X}^{2}$ tabel $(\alpha=0,05)$ & Keterangan \\
\hline Warna & 5,120 & 1 & 3,84 & Berbeda nyata \\
Jenis kelamin & 18,000 & 1 & 3,84 & Berbeda nyata \\
Ukuran tubuh & 34,640 & 3 & 7,81 & Berbeda nyata \\
Kondisi tubuh & 42,320 & 1 & 3,84 & Berbeda nyata \\
\hline
\end{tabular}

Menurut Sihombing (1997) dan Budaarsa (2012; 2014), berdasarkan warnanya, babi bali dapat dibedakan menjadi 2 yaitu; 1) yang berwarna hitam, dan 2) yang berwarna hitam dengan belang putih. Secara statistika responden mempunyai preferensi yang berbeda nyata terhadap kedua jenis warna tersebut. Responden juga mempunyai preferensi yang berbeda terhadap jenis kelamin jantan maupun betina.

Preferensi responden terhadap babi bali sebagai bahan baku babi guling dapat diketahui dengan melihat kategori atau kriteria atribut yang paling banyak dipilih oleh responden. Babi bali yang disukai oleh responden sebagai bahan baku babi guling adalah babi bali jantan yang berwarna hitam dengan berat sekitar 10-15 kg dan kondisi tubuhnya gemuk, seperti yang dapat dilihat pada Tabel 2.

Warna babi bali yang paling disukai oleh responden adalah hitam. Hal ini terjadi karena konsumen menganggap bahwa yang berwarna hitam adalah babi bali asli. Sedangkan yang ada belang putihnya sudah dianggap tidak asli atau dianggap sudah merupakan hasil kawin silang. 
Tabel 2. Preferensi responden terhadap atribut babi bali

\begin{tabular}{|c|c|c|}
\hline Atribut Babi Bali & Pilihan & $\begin{array}{l}\text { Preferensi } \\
\text { Responden }\end{array}$ \\
\hline Warna & $\begin{array}{l}\text { 1. Hitam } \\
\text { 2. Hitam dengan belang putih }\end{array}$ & Hitam \\
\hline Jenis Kelamin & $\begin{array}{l}\text { 1. Jantan } \\
\text { 2. Betina }\end{array}$ & Jantan \\
\hline Ukuran Tubuh & $\begin{array}{l}\text { 1. Kecil }(10-15 \mathrm{~kg}) \\
\text { 2. Sedang } 16-25 \mathrm{~kg} \\
\text { 3. Besar }(26-35 \mathrm{~kg}) \\
\text { 4. Sangat Besar }(>35 \mathrm{~kg})\end{array}$ & Kecil \\
\hline Kondisi Tubuh & $\begin{array}{l}\text { 1. Kurus } \\
\text { 2. Sedang } \\
\text { 3. Gemuk }\end{array}$ & Gemuk \\
\hline
\end{tabular}

Responden lebih menyukai jenis kelamin jantan dibandingkan yang betina. Daging babi bali jantan dianggap lebih banyak dan bentuk tubuhnya lebih bagus. Pada babi bali yang betina kemungkinan memiliki alat reproduksi yang lebih berat sehingga jumlah karkas yang diperoleh lebih sedikit. Responden juga lebih menyukai babi bali yang kondisi tubuhnya gemuk, karena bentuk babi guling yang dihasilkan akanlebih bagus dan kompak serta dagingnya lebih banyak.

Berdasarkan ukuran tubuhnya, babi bali dapat digolongkan menjadi kategori kecil, sedang, besar, dan sangat besar. Babi bali yang paling disukai oleh responden adalah babi bali yang berukuran kecil dengan berat $10-15 \mathrm{~kg}$. Ukuran tersebut di rasa sangat pas baik untuk pelengkap sesaji maupun untuk konsumsi. Ukuran berat babi di bawah $10 \mathrm{~kg}$ kurang disukai karena responden menganggap bahwa babi tersebut tingkat stressnya lebih tinggi, sehingga lebih rentan terhadap penyakit diarhea sehingga sering mengalami kematian pada saat penampungan sementara di kandang stok. Ukuran yang lebih besar kurang disukai oleh produsen karena permintaan konsumen sedikit. Hal ini kemungkinan disebabkan karena harganya yang lebih tinggi di bandingkan dengan yang kecil.

\section{Keyakinan dan Evaluasi Responden terhadap Atribut-Atribut Babi Bali}

Sikap responden menggambarkan kepercayaan atau keyakinan dan evaluasi responden terhadap berbagai atribut dan manfaat dari bali bali tersebut. Keyakinan tersebut menunjukkan keyakinan responden bahwa produk yang ia beli memiliki atribut-atribut yang baik. Sedangkan eavluasi responden menunjukkan sejauh mana tingkat kepentingan atribut produk tersebut bagi responden.

Atribut warna, jenis kelamin, dan ukuran tubuh memiliki skor keyakinan (bilief) lebih dari 4 dari skor maksimum 5 (Tabel 3). Hal ini menunjukkan bahwa responden mempunyai keyakinan bahwa babi bali hasil peternak yang ia beli adalah babi yang mempunyai warna, jenis kelamin, dan ukuran tubuh yang baik atau sesuai dengan harapan. Sedangkan atribut kondisi tubuh skornya masih rendah yaitu hanya 2,9 dari skor maksimum 5, yang artinya bahwa babi bali yang ada di pasaran kondisi tubuhnya belum sesuai harapan karena sebagian besar masih kurus. Hal ini kemungkinan terjadi karena sistem pemeliharaan babi bali yang sebagian besar masih bersifat tradisional dengan pakan yang kurang bergizi sehingga kondisi tubuhnya tidak maksimal. Hal ini didukung oleh Budaarsa et al. (2016) yang menyatakan bahwa sebagian besar sistem pemeliharaan babi bali dilakukan secara tradisional dengan cara mengikat babi tersebut di bawah pohon dan diberikan pakan seadanya sesuai dengan apa yang dimiliki oleh peternak.

Tabel 3. Keyakinan responden $\left(b_{i}\right)$ terhadap atribut babi bali

\begin{tabular}{|c|c|c|c|c|c|c|c|}
\hline \multirow{2}{*}{$\begin{array}{c}\text { Atribut Babi } \\
\text { Bali }\end{array}$} & \multicolumn{5}{|c|}{ Skor } & \multirow{2}{*}{ Total } & \multirow{2}{*}{$b_{i}$} \\
\hline & 5 & 4 & 3 & 2 & 1 & & \\
\hline \multirow[t]{2}{*}{ Warna } & 25 & 15 & 10 & 0 & 0 & 50 & 4,30 \\
\hline & 125 & 60 & 30 & 0 & 0 & 215 & \\
\hline \multirow[t]{2}{*}{ Jenis Kelamin } & 14 & 36 & 0 & 0 & 0 & 50 & 4,28 \\
\hline & 70 & 144 & 0 & 0 & 0 & 214 & \\
\hline \multirow[t]{2}{*}{ Ukuran Tubuh } & 16 & 29 & 5 & 0 & 0 & 50 & 4,22 \\
\hline & 80 & 116 & 15 & 0 & 0 & 211 & \\
\hline \multirow[t]{2}{*}{ Kondisi Tubuh } & 0 & 5 & 35 & 10 & 0 & 50 & 2,9 \\
\hline & 0 & 20 & 105 & 20 & 0 & 145 & \\
\hline
\end{tabular}

Hasil evaluasi responden terhadap atribut babi bali menunjukkan bahwa atribut yang sangat penting bagi responden dalam keputusan membeli babi bali adalah ukuran tubuh dan kondisi tubuh, dengan nilai skor masing-masing sebesar 5 dan 4,7 dari skor maksimum 5 seperti yang dapat dilihat pada Tabel 4. Sedangkan warna dan jenis kelamin dianggap tidak begitu penting dengan skor masing-masing sebesar 2,10 dan 2,16 dari skor maksimum 5. Terkait dengan babi guling sebagai pelengkap sesaji, konsumen kadangkala meminta dibuatkan babi guling dari babi bali dengan warna dan jenis kelamin tertentu.

Tabel 4. Hasil evaluasi responden (ei) terhadap atribut babi bali

\begin{tabular}{lccccccc}
\hline \multirow{2}{*}{$\begin{array}{c}\text { Atribut Babi } \\
\text { Bali }\end{array}$} & 5 & 4 & 3 & 2 & 1 & Total & $\begin{array}{c}\text { Rata- } \\
\text { rata }\end{array}$ \\
\cline { 2 - 5 } Warna & 0 & 0 & 15 & 25 & 10 & 50 & \\
\multirow{5}{*}{ Jenis Kelamin } & 0 & 0 & 45 & 50 & 10 & 105 & 2,10 \\
& 0 & 5 & 14 & 15 & 16 & 50 & \\
Ukuran Tubuh & 50 & 0 & 0 & 0 & 0 & 50 & \\
\multirow{3}{*}{ Kondisi Tubuh } & 250 & 0 & 0 & 0 & 0 & 250 & 5,00 \\
& 175 & 15 & 0 & 0 & 0 & 50 & \\
& 60 & 0 & 0 & 0 & 235 & 4,70 \\
\hline
\end{tabular}

Berdasarkanhasilanalisis sikap multiatribut Fishbein dapat diketahui bahwa atribut yang dipertimbangkan 
oleh responden dalam keputusan pembelian babi bali berturut-turut dari yang paling dipertimbangkan sampai dengan yang kurang dipertimbangkan adalah ukuran tubuh, kondisi tubuh, jenis kelamin, dan warna seperti yang dapat dilihat pada Tabel 5 .

Tabel 5. Sikap responden terhadap atribut babi bali

\begin{tabular}{lcccc}
\hline \multicolumn{1}{c}{ Atribut Babi Bali } & $\begin{array}{c}\text { Keyakinan } \\
\text { (skor max 5) }\end{array}$ & $\begin{array}{c}\text { Evaluasi } \\
\text { (skor max 5) }\end{array}$ & $\begin{array}{c}\text { Sikap } \\
\text { (Skor maksi- } \\
\text { mum 25) }\end{array}$ & Peringkat \\
\hline Warna & 4,30 & 2,18 & 9,37 & 3 \\
Jenis kelamin & 4,28 & 2,16 & 9,24 & 4 \\
Ukuran tubuh & 4,22 & 5,00 & 21,10 & 1 \\
Kondisi ubuh & 2,90 & 4,70 & 13,63 & 2 \\
\hline
\end{tabular}

\section{SIMPULAN}

Atribut utama dari babi bali yang dipertimbangkan oleh responden dalam keputusan pembelian babi bali berturut-turut dari yang paling dipertimbangkan sampai dengan yang kurang dipertimbangkan adalah ukuran tubuh, kondisi tubuh, warna, dan jenis kelamin. Babi bali yang menjadi preferensi bagi produsen babi guling adalah babi bali jantan berwarna hitam yang berukuran kecil (10-15 kg) dan kondisi tubuhnya gemuk.

\section{UCAPAN TERIMAKASIH}

Pada kesempatan ini kami selaku tim peneliti mengucapkan terimakasih yang sebesar-besarnya kepada Bapak Rektor, Ketua Lembaga Penelitian dan Pengabdian Masyarakat, dan Dekan Fakultas Peternakan Universitas Udayana atas kepercayaan dan kesempatan yang diberikan untuk melakukan penelitian ini. Kami juga mengucapkan terimakasih kepada para produsen babi bali guling dan semua pihak yang telah membantu sehingga kegiatan ini dapat berjalan sesuai dengan harapan.

\section{DAFTAR PUSTAKA}

Budaarsa, K. 2012. Babi Guling Bali. Buku Arti. Denpasar.

Budaarsa, K. 2014. Potensi Ternak Babi dalam Pemenuhan Daging di Bali. Prosiding Seminar dan Lokakarya Nasional Ternak Babi. Fakultas Peternakan, Universitas Udayana. Denpasar.

Budaarsa, K., A.W. Puger, dan I M. Suasta. 2016. Exsplorasi komposisi pakan tradisional babi bali. Majalah Ilmiah Peternakan 1(19): 6-11.

Sihombing, D.T.H. 1997. Ilmu Ternak Bali. Gajah Mada University Press. Yogyakarta.

Siegel, S. 1997. Statistik Non Parametrik untuk Ilmu-Ilmu Sosial. Gramedia. Jakarta.

Suarna, I W. dan N. N. Suryani. 2014. Peluang dan Tantangan Pengembangan Ternak Babi Bali di Kabupaten Gianyar Provinsi Bali. Prosiding Seminar dan Lokakarya Nasional Ternak Babi. Fakultas Peternakan, Universitas Udayana. Denpasar.

Wirawan, N. 2002. Statistik 2 (Statistik inferensia). Edisi kedua. Keraras Emas. Denpasar. 